\title{
University and Universality. 650. výročí pécské univerzity
}

Univerzita $\mathrm{v}$ jihomad’arské Pécsi se považuje za nejstarší univerzitní fundaci na území Mad’arska, ale i někdejšího Uherského království. Zakladatel pécské univerzity, král Ludvík I. Uherský z rodu Anjou, našel při jejím založení vzor v Praze a Vídni, jak zaznělo v úvodních vystoupeních konference, uspořádané u př́iležitosti 650 . výročí založení univerzity, konané ve dnech 11.-13. ř́jina 2017.

Fungování pécské univerzity sice bylo ve středověku krátké, omezilo se na období 1367-1376, nicméně škola stihla vychovat několik ročníků vzdělanců, kteří ovlivnili situaci nejen ve své zemi. Od josefínských dob se datují pokusy univerzitu do Pécse vrátit. Trvale zaujala podstatné místo v mad'arském vzdělávacím systému až v roce 1923. V dnešní době má pécská univerzita deset fakult a studuje na ní přes 17000 studentů.

Konference k výročí univerzity byla pořádána pod záštitou pécského biskupa György Udvardyho, který zde na úvod vystoupil se zdravicí, a pod záštitou rektora univerzity Józsefa Bódise, který rovněž pozdravil účastníky.

Úvodní referát, přibližující dějiny vysokoškolského vzdělání a jeho současný stav přednesla Ágnes F. Dárdai, vedoucí univerzitní knihovny. Zahajující odbornou přednášku s tématem Jüngere Forschungen zur Geschichte der Universitäten und Gelehrten im deutschsprachigen Raum, v níž byla velká pozornost věnována i pražské univerzitě v období středověku, pronesl Christian Hesse (University of Bern, Switzerland). Na něj navázal László Szögi (Eötvös Loránd University, Hungary) a shrnul stav univerzitní historiografie v Mad’arsku a mezinárodní spolupráci na tomto poli.

Dále konference pokračovala ve dvou oddělených sekcích, rozdělených chronologicky. Sekci věnující se středověkým univerzitám předsedal István Draskóczy (Eötvös Loránd University, Hungary). První referát přednesla Márta Font (University of Pécs, Hungary) a věnovala se nadějím, které byly vkládány do založení zejména pécské univerzity a pozadí neúspěchu, který pár let po založení nastal, když univerzita skončila (The Hope of Success and the Background of the Failure: Establishing Universities in Medieval Hungary). Tamás Fedeles (University of Pécs, Hungary) vysvětlil strukturu a koncepci stř̌edověké pécské univerzity (...in dicta civitate Quinque Ecclesiensi de cetero sit studium generale). Kurt Mühlberger (Vienna University, Austria) uvedl pécskou univerzitu do kontextu středověkých vysokých učení na území pozdější habsburské monarchie (Wege und Methoden der Universitätsgeschichte in Österreich). Posledním př́spěvkem této části zasedání bylo vystoupení Adinel Ciprian Dinca (Babes-Bolyai University, Romania) o neznámých rukopisech původem ze středověkých univerzit na př́kladu Transylvánie (Unknown Manuscripts from Medieval Universities. Some Examples from Transylvania).

Paralelní zasedání pak bylo více zaměřeno na další univerzity v habsburské monarchii. István Monok (Hungarian Academy of Sciences, Library, Hungary) se věnoval roli odborných knihoven ve vědeckém výzkumu (Die Rolle der Fachbibliotheken im Kampf um die Meinungsfreiheit der wissenschaftlichen Forschungen. Eine europäische Geschichte mit ungarischen Beispielen). Další tři př́spěvky byly věnovány zejména univerzitní historiografii, a to od Krzysztofa Ożóga (Jagiellonian University, Poland) na krakovské univerzitě (Krakauer Universität in XIV.-XVIII. Jahrhundert. Forschungsstand, Methoden und Impulse für neue Fragestellungen), od Milady Sekyrkové (Univerzita Karlova) na pražské univerzitě (Parallelen und Unterschiede in der Geschichte der Universitäten in Pécs und 
Prag) a od Márie Grófové (Univerzita Komenského Bratislava) na bratislavské univerzitě (Slowakische Historiographie der Hochschulbildung).

Jednání v paralelních sekcích pokračovalo i druhý den konference. Středověký blok měl dva směry. Jednak se věnoval studentům $\mathrm{z}$ Uher na zahraničních univerzitách $\mathrm{v}$ době, kdy v Uhrách žádná univerzita nefungovala. István Draskóczy (Eötvös Loránd University, Hungary) se v tomto smyslu věnoval uherským studentům v Krakově a Vídni (Ungarn - ein Land ohne Universitäten. Studenten aus Ungarn an der Universitäten in Wien und Krakau zur Zeit der Jagellonen [1490-1526]), a Borbála Kelényi (Eötvös Loránd University, Hungary) uherským studentům na vídeňské univerzitě (Students from the medieval Hungarian Kingdom at the University of Vienna. Additional data to their studies: Faculties and graduation). Další dva referáty se vrátily k situaci v Pécsi. Miklós Boda (emeritní knihovník) se zaměřil na poznatky o tom, co předcházelo založení pécské univerzity (Beiträge zur Vorgeschichte des ,,studium generale Quinqueecclesiense”). Péter Haraszti-Szabó (Eötvös Loránd University, Hungary) přednesl životopisnou črtu (An unknown professor at the medieval University of Pécs?).

Druhá sekce šla obecnějším směrem. V prvním př́spěvku se István Lengvári (University of Pécs, Hungary) věnoval přehledu složení pedagogického sboru pécské univerzity po jejím obnovení ve 20. letech 20. století (Professors of the Pécs Erzsébet University [1923-1950]). Petra Polyák (University of Pécs, Hungary) sledovala univerzitní jubilea v Pécsi v průběhu 20. století (Universitätsjubiläen in Pécs im 20. Jahrhundert). Na obecnější rysy vzdělávání na území Mad’arska v novověku (Die Entwicklungsperioden der ungarischen Erziehungswissenschaft im 19. und 20. Jahrhundert) se zaměřil András Németh (Eötvös Loránd University, Hungary). Pohled na současné trendy v konceptech vzdělávání (Trends in Higher Education in Europe in the 21st Century) nabídla Csilla Stéger (Education Office, Budapest, Hungary) na závěr tohoto bloku.

Poslední, opět společné zasedání se věnovalo výhradně tematice knihoven a knihovnictví, protože právě knihovníci pécské univerzity byli hlavními organizátory této jubilejní konference. Éva Schmelczer-Pohánka (University of Pécs, Hungary) poreferovala o knižních sbírkách katolických vzdělávacích institucí v Pécsi ve středověku a raném novověku (Die Büchersammlung der katholischen kirchlichen Hochschulbildung in Fünfkirchen von Anfang bis zum Ende des 18. Jahrhunderts). Vedoucí knihovny, Ágnes F. Dárdai (University of Pécs, Hungary), se věnovala trendům ve vedení knihovny v 30. a 40. letech 20. století (Reformer-Direktoren der Bibliothek der Erzsébet Universität [1930-1942]). Vědeckou část konference uzavřelo vystoupení Istvána Moldována (National Széchényi Library, Hungary) s úvahou o dalším směřování knihoven v 21. století (Who saves the Memories for the Future? Libraries in the 21st Century).

Konference prezentovala stav znalostí nejen o pécské univerzitě, ale i o vývoji a stavu univerzitní historiografie ve střední Evropě a přinesla četné podnětné debaty nejen v rámci zasedání, ale i při bohatém doprovodném programu, který zahrnoval prohlídku středověkých staveb, kde se předpokládaly prostory univerzity, a prohlídku cenné univerzitní knihovny.

Milada Sekyrková

doi: $10.14712 / 23365730.2018 .58$ 